\title{
An Intensive Pedestrian Archaeological Survey of the Salado Creek Greenway, Wetmore Avenue to Eisenhauer Road, San Antonio, Bexar County, Texas Phase II: N. E. Loop 410 to Wetmore Avenue
}

Antonia L. Figueroa

Center for Archeological Research, University of Texas at San Antonio

Follow this and additional works at: https://scholarworks.sfasu.edu/ita

Part of the American Material Culture Commons, Archaeological Anthropology Commons, Environmental Studies Commons, Other American Studies Commons, Other Arts and Humanities Commons, Other History of Art, Architecture, and Archaeology Commons, and the United States History Commons

Tell us how this article helped you.

This Article is brought to you for free and open access by the Center for Regional Heritage Research at SFA ScholarWorks. It has been accepted for inclusion in Index of Texas Archaeology: Open Access Gray Literature from the Lone Star State by an authorized editor of SFA ScholarWorks. For more information, please contact cdsscholarworks@sfasu.edu. 


\section{An Intensive Pedestrian Archaeological Survey of the Salado Creek Greenway,}

Wetmore Avenue to Eisenhauer Road, San Antonio, Bexar County, Texas Phase II: N. E. Loop 410 to Wetmore Avenue

Creative Commons License

(c) $(1)$ ( 8

This work is licensed under a Creative Commons Attribution-NonCommercial 4.0 International License 


\title{
An Intensive Pedestrian Archaeological Survey of the Salado Creek Greenway, Wetmore Avenue to Eisenhauer Road, San Antonio, Bexar County, Texas
}

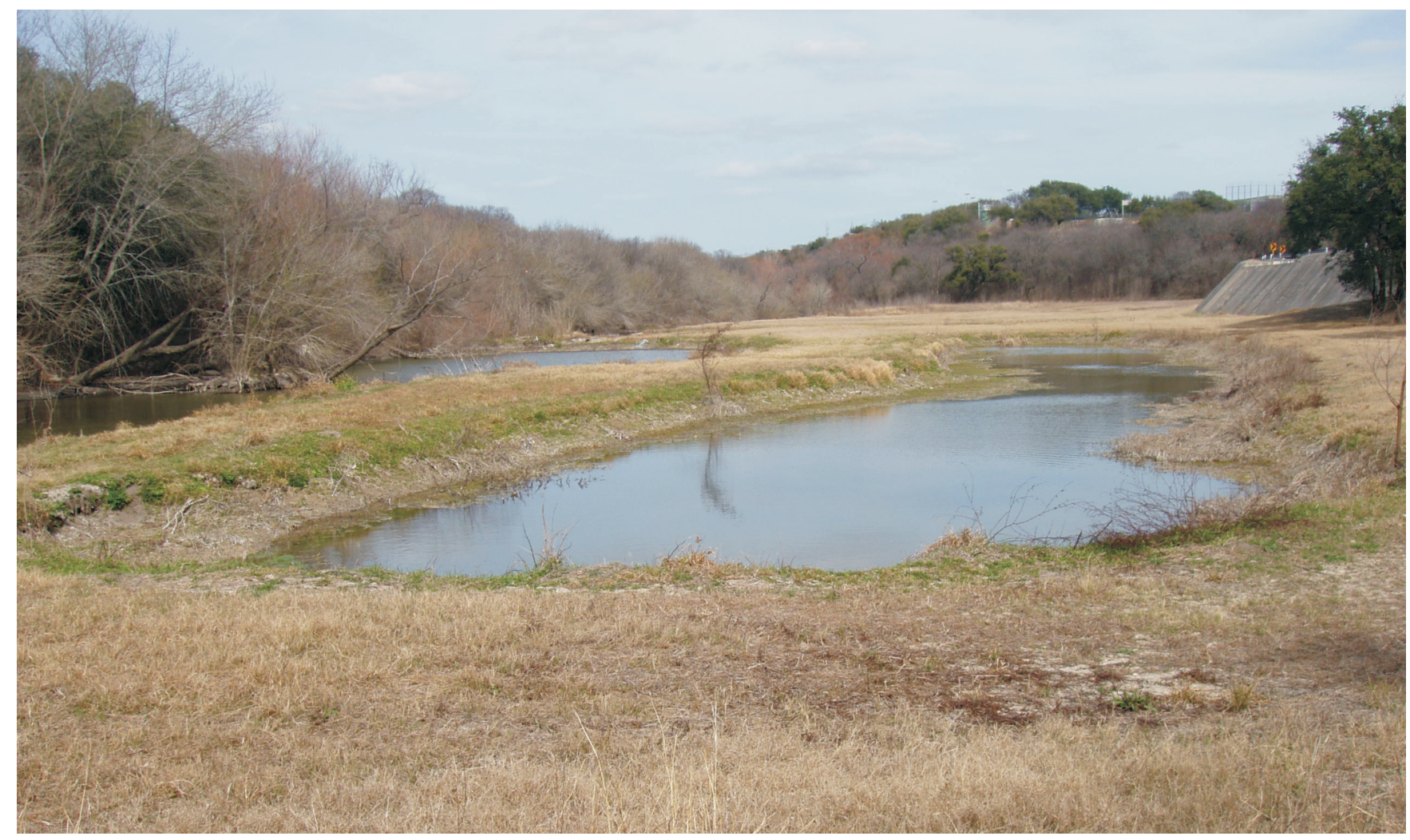

\section{Phase II: N. E. Loop 410 to Wetmore Avenue}

\author{
by \\ Antonia L. Figueroa
}

Principal Investigator

Raymond P. Mauldin

Texas Antiquities Permit No. 4561

Prepared for:

Adams Environmental Inc.

12018 Las Nubes

San Antonio, Texas 78233

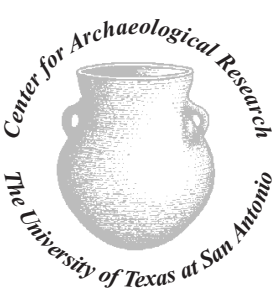

(C)2008
Prepared by:

Center for Archaeological Research The University of Texas at San Antonio Archaeological Report, No. 395 


\title{
An Intensive Pedestrian Survey of the Salado Creek Greenway, Wetmore Avenue to Eisenhauer Road, San Antonio, Bexar County, Texas Phase II: N.E. Loop 410 to Wetmore Avenue
}

\author{
by
}

Antonia L. Figueroa

Texas Antiquities Committee Permit No. 4561

Principal Investigator

Raymond P. Mauldin

Prepared for:

Adams Environmental Inc. 12018 Las Nubes San Antonio, Texas 78233

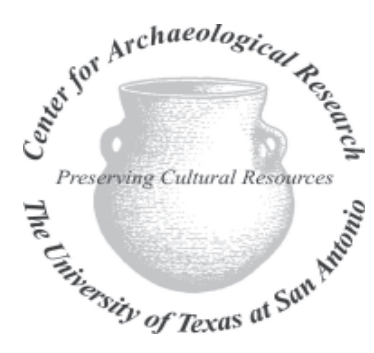

Center for Archaeological Research The University of Texas at San Antonio Archaeological Report, No. 395 



\begin{abstract}
:
The Center for Archaeological Research (CAR) of The University of Texas at San Antonio conducted an intensive pedestrian archaeological survey of the Salado Creek Greenway project located in San Antonio, Bexar County, Texas to fulfill contract requirements with Adams Environmental, Inc. of San Antonio. The survey was conducted under the requirements of the City of San Antonio Unified Development Code Chapter 35, Section 106 of the National Historic Preservation Act (NHPA) of 1966, and the Texas Antiquities Code. The survey was performed under Texas Antiquities Permit No. 4561, with Dr. Raymond Mauldin, CAR Assistant Director, serving as Principal Investigator and Antonia L. Figueroa serving as the Project Archaeologist. The work was conducted in advance of construction of a multi-use greenway trail proposed by the Parks and Recreation Department of the City of San Antonio.
\end{abstract}

The project consists of development of a multi-use greenway trail running from Wetmore Avenue to Eisenhauer Road along the Salado Creek channel. The project area was surveyed in two phases with the first phase from N.E. Loop 410 to Eisenhauer Road completed in August 2007 (Munoz 2008) and the second phase from N.E. Loop 410 to Wetmore Avenue completed in February 2008. This report summarizes the results of the fieldwork from Phase II and provides recommendations regarding the management of cultural resources located on the project area.

The archaeological investigations conducted by CAR resulted in the identification and recording of three new sites (41BX1764, 41BX1765 and 41BX1766). A portion of site 41BX841 was revisited as part of the pedestrian survey. However, the proposed trail alignment will not impact the site. The CAR recommends that sites 41BX1765 and 41BX1766 are not eligible for nomination to the National Register of Historical Places (NRHP). Shovel testing at 41BX1764 suggests the site is potentially eligible for the NRHP under criterion D. Because the site is located on the proposed trail alignment, the CAR recommends eligibility testing of the 41BX1764.

All materials recovered during the investigations and all project related documents are curated at the Center for Archaeological Research. 


\section{Table of Contents:}

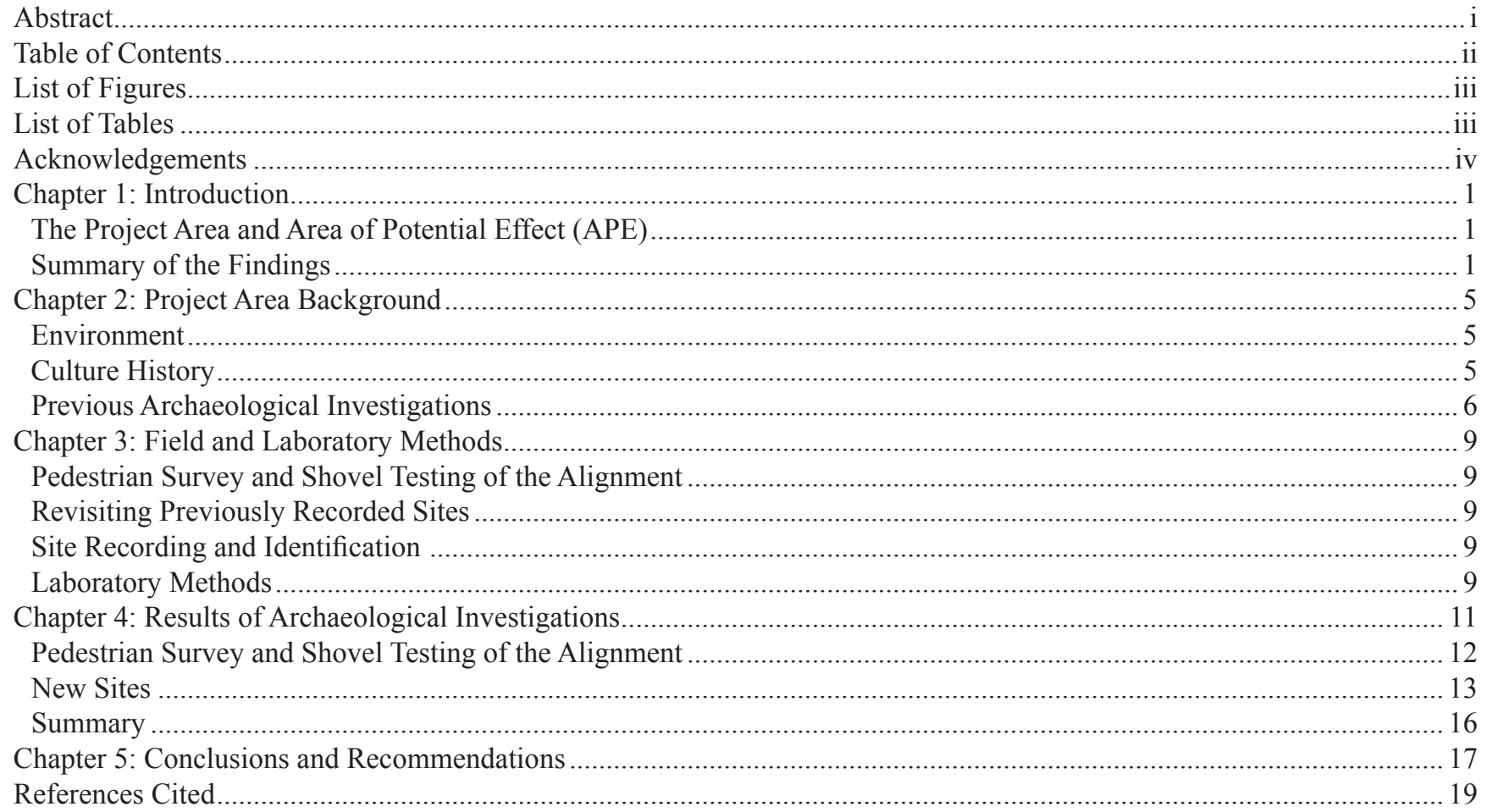




\section{List of Figures:}

Figure 1-1. The location of the project area on the Longhorn and San Antonio East 7.5 Minute Series

USGS quadgrangle maps (note Phase II is highighted in red and Phase I in blue).........................................................2

Figure 1-2. Aerial photograph depicting the project area (note Phase II is highlighted in red and Phase I in blue) ................... 3

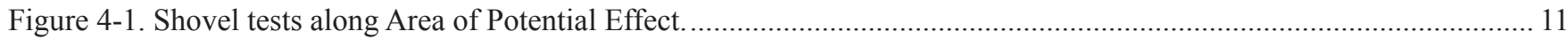

Figure 4-2. Gravels associated with landscaping activities along the Los Patios portion of the project area.......................... 12

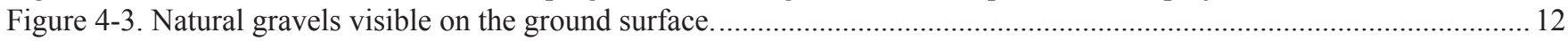

Figure 4-4. Residential properties bounding the Salado Creek channel, north of Nacogdoches Road. ................................. 13

Figure 4-5. A map showing the location of shovel tests and the site boundaries of 41BX1764........................................ 13

Figure 4-6. Line graph showing the distribution of cultural material, per level, at 41BX1764 …...................................... 14

Figure 4-7. A map showing the location of shovel tests and the site boundaries of 41BX1765 ........................................ 15

Figure 4-8. A map showing the location of shovel tests and the site boundaries of 41BX1766........................................ 16

\section{List of Tables:}

Table 4-1. Cultural Material Recovered from Shovel Testing at 41BX1764 


\section{Acknowledgements:}

The completion of this project would not have been possible without the field crew. They included the following individuals from the Center for Archaeological Research: Nathan Devito, Jason Perez, and Joseph Thompson. Dr. Raymond Mauldin served as Principal Investigator on the project. Ms. Cynthia M. Munoz directed the Phase II project, gave comments on the draft report and provided support throughout its completion. The author would also like to thank Leonard Kemp for aiding with field logistics, Bruce Moses for drafting report figures, and Jennifer Thompson for producing the final manuscript. The author thanks Brian Gottschalk and Lynn Kitchen, both of Adams Environmental, Inc., and Kay Hindes, Archaeologist for the City of San Antonio. 


\section{Chapter 1: Introduction}

The Center for Archaeological Research (CAR) of The University of Texas at San Antonio was contracted by Adams Environmental Inc. of San Antonio to conduct an intensive pedestrian archaeological survey for the Salado Creek Greenway project located in San Antonio, Bexar County, Texas (Figure 1-1). The pedestrian survey and shovel testing was conducted in February 2008 in advance of the proposed construction of a hike and bike trail. The main goal of the pedestrian survey was to identify and document all prehistoric and historic archaeological sites that may be impacted by the proposed improvements within the specific Area of Potential Effect (APE). The archaeological survey was performed under Texas Antiquities Permit No. 4561, with Dr. Raymond Mauldin, CAR Assistant Director, serving as Principal Investigator and Antonia L. Figueroa serving as Project Archaeologist.

The land impacted by the project is owned by the City of San Antonio, a political subdivision of the State of Texas. As such, the project has to comply with the mandates of the Antiquities Code of Texas. The work was also coordinated through the City's Historic Preservation Office in compliance with the City of San Antonio Unified Development Code Chapter 35. In addition, because the project area is located along a waterway and a bridge will have to be constructed across Salado Creek, a 404 Nationwide Permit will have to be issued by the Corps of Engineers (COE). Projects receiving federal funding and/or permitting must comply with Section 106 of the National Historic Preservation Act (NHPA) of 1966. One outcome of the NHPA was the creation of the National Register of Historic Places (NRHP) and the Advisory Council of Historic Preservation. Section 106 of the NHPA stipulates that the Advisory Council must be given "a reasonable opportunity to comment" regarding the effect of any undertakings that could impact properties that may be eligible for inclusion in the National Register. All undertakings that derive from actions funded by, permitted by, or licensed by federal agencies fall under this requirement.

\section{The Project Area and Area of Potential Effect (APE)}

The project area was surveyed in two phases and is depicted on the Longhorn and San Antonio East, Texas USGS 7.5' quadrangles. The project area is within the Salado watershed in north-central San Antonio bordered by Wetmore Avenue to the northwest and Eisenhauer Road to the south. Loop 410 bisects the project area from the east to the west. The first phase spanned from N.E. Loop 410 to Eisenhauer Road (Munoz
2008) and measured two miles (3,219 meters) long. This report focuses on the second phase that spans from N.E. Loop 410 to Wetmore Avenue. The second phase is approximately two and a half miles (4,023 meters; Figure 1-2) in length. A third segment of the trail corridor, north of Wetmore Avenue, was to be included in the Phase II work. This third portion of the trail corridor has not been finalized by the client. Once the proposed route has been decided further work may be recommended. Results of the survey of that portion of the trail may be presented in a separate report.

The APE consists of a multi-use greenway trail, trailhead, trail switchbacks, signage, and a parking lot. The parking lot will be built up from the existing surface elevations using additional fill and will consist of an 8 inch $(.20 \mathrm{~m})$ deep layer of asphalt. Thus, no excavation is anticipated during parking lot construction. Signage along the trail and at the trail head will require footings that could go as deep as 24 to 36 inches $(.61-.91 \mathrm{~m})$. The right-of-way (ROW) is approximately 20 meters wide but varies in different locations of the project area. The proposed project is part of the City's long-range plan to maintain, improve, and expand existing multi-use greenway trails.

\section{Summary of the Findings}

The intensive pedestrian survey along the Salado Creek resulted in the excavation of 48 shovel tests. Three new sites (41BX1764, 41BX1765 and 41BX1766) were documented and site $41 \mathrm{BX} 841$ was revisited as part of the survey. We do not recommend newly recorded sites 41BX1765 and 41BX1766 eligible for listing in the NRHP. However, the CAR recommends eligibility testing be conducted on 41BX1764. 


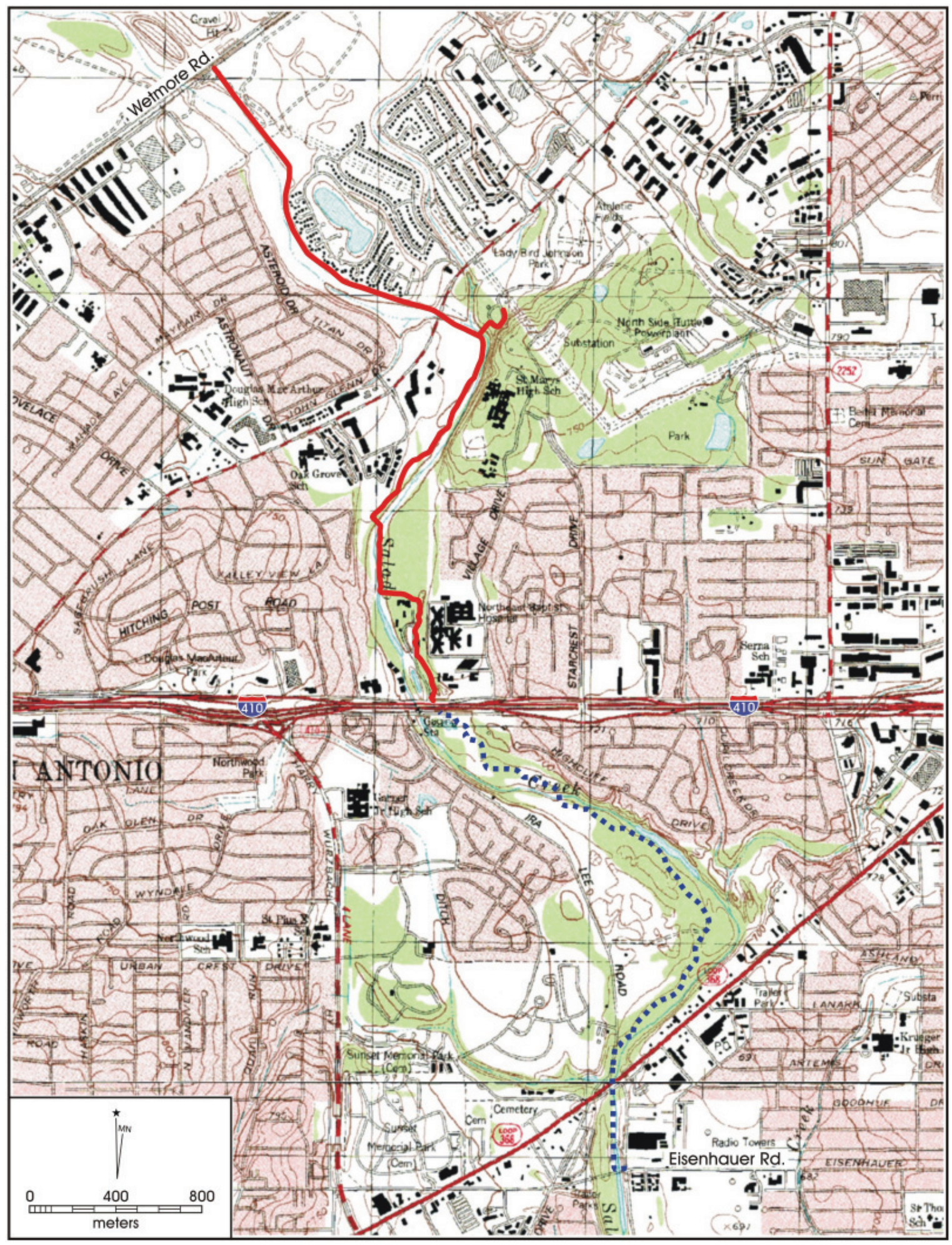

Figure 1-1. The location of the project area on the Longhorn and San Antonio East 7.5 Minute Series USGS quagrangle maps (note Phase II is highlighted in red and Phase I in blue). 


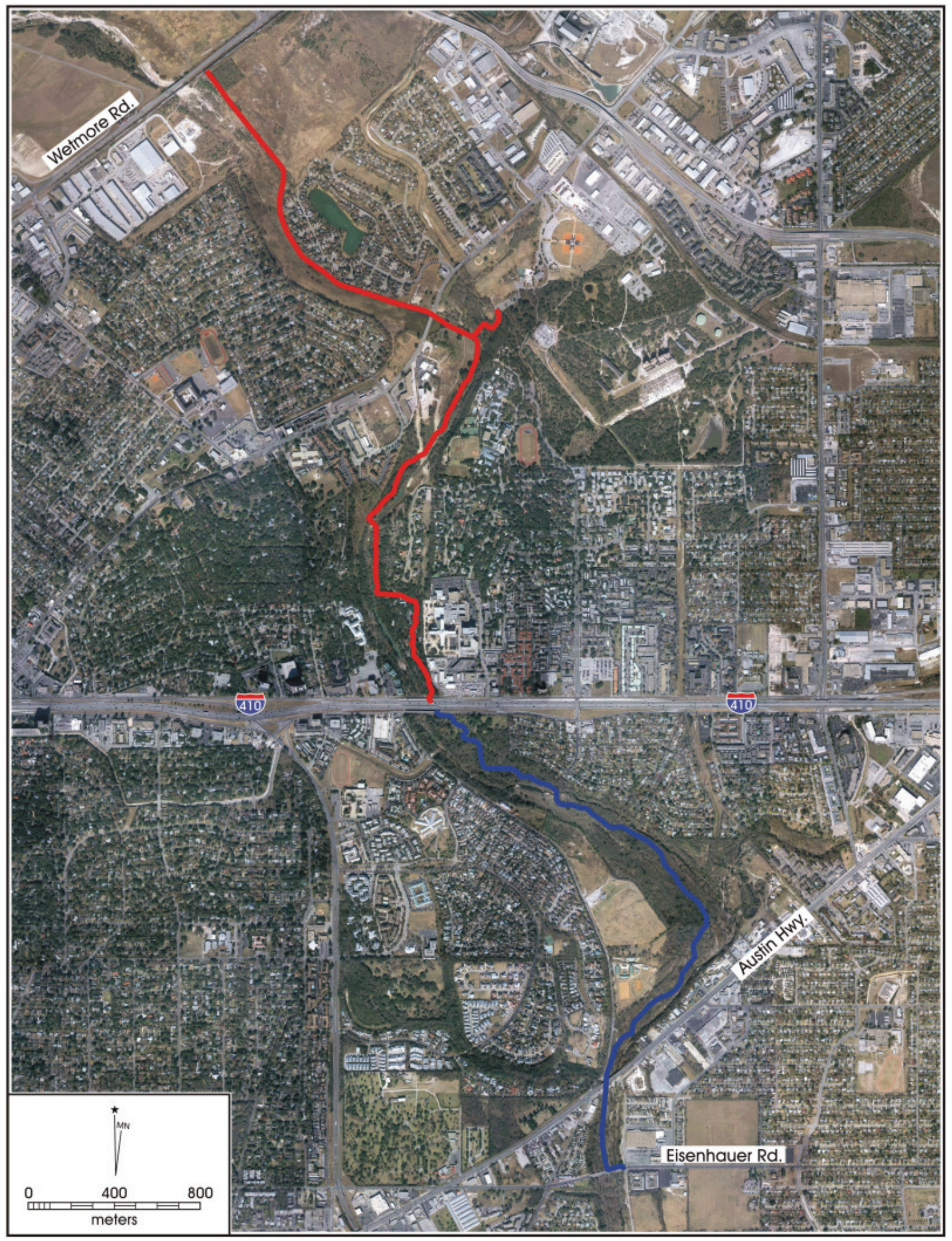

Figure 1-2. Aerial photograph depicting the project area (note Phase II is highlighted in red and Phase! in blue). 



\section{Chapter 2: Project Area Background}

The project area is located in northeast Bexar County, San Antonio, Texas. This chapter discusses the project area environs, including the Salado Creek watershed, physiographic region, vegetation and soils. The culture history for SouthCentral Texas and a summary of the previous archaeology in the area are also included.

\section{Environment}

The project area is within a transitional zone between two major physiographic regions: the South Texas Brush Country to the south and the Edward's plateau to the north. These physiographic regions contain biotic zones that create a prime environment for a variety of flora and fauna. Limestone foothills that represent the Balcones Escarpment extend from northern Bexar County southwest into the area of Del Rio, on the Rio Grande River. The typical topography is represented by rugged terrain in the form of low steep hills cross-cut by several small intermittent streams.

Vegetation in the area consists of typical South Texas scrub and grass species, including mesquite (Prosopis glandulosa), live oak (Quercus virgininana), pecan (Carya illnoinensis), Texas persimmion (Diospyros texana) and prickly pear cactus (Opuntia engelmanni; Vines 1960).

Potter et al. (1995) have defined the Salado Creek System by Upper, Middle and Lower reaches. The three sections of the Salado watershed are classified by stream gradient and depositional patterns. The project area is within the Middle Salado watershed (Potter et al. 1995). The Middle Salado is defined as a 25 linear $\mathrm{km}$ portion of the drainage that begins at its confluence with Panther Springs and ends $20 \mathrm{~km}$ above its confluence with the San Antonio River.

The soils in the immediate vicinity of the active channel are described as frequently flooded Trinity and Frio Soils (Tf). These soils occur as narrow, irregularly shaped areas on the flood plains of small streams and large drainages. Trinity/ Frio soils range from one to one and one half meters deep and consist of a surface layer of clay loam and a subsurface layer of clay with pockets of thin loamy strata (Taylor et al. 1991). The soils abutting the active channel are identified as Lewisville silty clays (Lv), Patrick soils (Pa), and Tarrant association (Ta). The Lewisville series consists of moderately deep, dark colored, alluvial soils. Patrick soils contain shallow, calcareous clay loam. The Tarrant series is characterized by gently undulating, stony, clay loam overlying shallow bedrock. A small segment of the soils adjacent to the active channel near the southern end of the project area are identified as Pits and Quarries (Pt). This land type consists of clay, gravel and sand pits, limestone, chalk and rock quarries, and city dumps (Taylor et al. 1991).

\section{Culture History}

The culture history of the region spans nearly 11,500 years. There are four culture periods that are discernable by changes in hunting and gathering technologies and material culture: Paleoindian, Archaic, Late Prehistoric and Historic. Culture histories of both South and Central Texas were used in developing this section of the report, with primary sources including Collins (1995) and Hester (1995).

\section{Paleoindian Period}

The earliest culture and the entrance of humans in the New World occurred during the Paleoindian period which dates from 11,500-8800 BP (Collins 1995). It is further divided into Early and Late Paleoindian. Material culture from early Paleoindian is characterized by Clovis and Folsom fluted projectile points utilized in hunting of megafauna. Unfluted points such as Golondrina and Scottsbluff are diagnostic of the late Paleoindian. The marked changes in lithic technology coincide with changes in species hunted.

\section{Archaic Period}

This period spans from ca. $880 \mathrm{BP}$ to $1200 \mathrm{BP}$. This culture period is distinguished by three phases: Early Archaic, Middle Archaic and Late Archaic. During the Archaic period there is a shift in subsistence to a greater emphasis on the exploitation of specific local environments. Hunting strategies focus mainly on medium to small game. The ecological changes that occurred throughout the long span of the Archaic period could account for the changes in material culture.

Hester (1995:436-438) places the Early Archaic between 7950 and 4450 BP based on Early Corner Notched and Early Basal Notched projectile points. Collins (1995:383) dates the Early Archaic period from 8800 to 6000 BP based initially on unstemmed point types such as the Angostura, now believed to be one of the first Early Archaic diagnostics. Middle Archaic materials date from about 6000 to 4000 BP, with 
increased occurrence of multi-use bifacial knives and burned rock middens (Collins 1995:383). Diagnostic points from this period include Bell, Andice, Taylor, Nolan, and Travis. The last interval of the Archaic falls between 4000-1200 BP (Collins 1995:384). Dart point diagnostics of the Late Archaic are somewhat smaller, triangular points with corner notches such as the Ensor and Ellis (Turner and Hester 1993). Other Late Archaic points include Bulverde, Pedernales, Marshall, and Marcos (Collins 1995).

\section{Late Prehistoric Period}

This period extends from ca. 1200 to $350 \mathrm{BP}$ and is marked by the introduction of the bow and arrow. Austin and Toyah Phases distinguish this culture period. A series of distinctive traits mark the shift from the Archaic to the Late Prehistoric period, including the technological shift to the bow and arrow and the introduction of pottery. During the Austin phase there was an increase in the use of burned rock middens (Black and Creel 1997). Diagnostic point types include Scallorn and Edwards (Collins 1995; Turner and Hester 1993). The Toyah subperiod of the Late Prehistoric suggests interaction between Central Texas and ceramic producing traditions in East and North Texas due to the presence of bone-tempered Leon Plain ceramics (Pertulla et al. 1995). Other technological traits of this phase include the diagnostic Perdiz point, alternately beveled bifaces, and more bison oriented processing kits out of reaction to flourishing bison populations (Ricklis 1992).

\section{Historic Period}

The Historic period is characterized by European contact with Native cultures in the Americas. While Spanish explorers had established their presence in Texas since the 1500s, European settlements, the Spanish in particular, became part of the Texas landscape beginning in the late 1600s. Mission settlements began to be established in Bexar County in 1718 with Mission San Antonio de Valero (Chapa 1997). The introduction of a new culture is reflected in settlement patterns and material culture.

\section{Previous Archaeological Investigations}

Archaeological sites are ubiquitous in the Salado Creek watershed and have been subject to several archaeological investigations. Archaeological sites in the environs of the project area are 41BX949, 41BX959, 41BX841, 41BX229, 41BX1007, 41BX17, 41BX271.

41BX949 was recorded by Frank Weir in 1991 (THC 2008). The site was investigated during a larger testing project of five sites along Wurzbach Parkway. It was found to have shallow deposits of artifacts in secondary contexts. The site was considered ineligible for nomination for the NRHP (Potter and Black 1995).

41BX959 is located along the east bank of Mudd Creek. When the site was originally recorded in 1991 by C. K. Chandler, it consisted of tested cobbles, burned rock, lithic debitage and tools. Much of the area had been cleared of vegetation (THC 2008). The site was revisited and shovel tested in 2005 by CAR as part of a project of the San Antonio International Airport (Figueroa and Thompson 2005). The site has been heavily disturbed by landscape modifications and clearing. The 2005 airport survey not only revealed the site to be much larger than originally recorded, but it also revealed a historic component. Along with historic artifacts recovered (ceramics and glass), the remnants of a building that appears on the 1953 Longhorn, TX 7.5 USGS quadrangle map of the area was also identified. Cultural material scattered on the surface of the site and recovered from the upper deposits of shovel tests included cores, bifaces and hammerstone flakes. Due to the extensive disturbance of the deposits and the lack of features the site did not warrant formal designation as a State Archeological Landmark and was not recommended as eligible for nomination to the National Register of Historic Places.

41BX841, located north of Loop 410 on the Lady Bird Johnson Park, was recorded by M. Kohnitz and identified as a lithic scatter. During the initial recording of the site no subsurface testing was conducted. No recommendations as to NRHP status were noted (THC 2008).

41BX229 (St. Mary's Hall site) is situated on a colluvial down slope of Salado Creek, approximately thirty-five meters east of the present channel. The site was recorded in 1974 by M. Kohnitz and T. Hester (THC 2008). No subsurface testing was conducted during its initial recording but cultural material observed on the surface included debitage, scattered burned rock, points, native ceramics, and a burned rock midden (THC 2008). The site was excavated in 1974 and 1975 by the Southern Texas Archaeological Association. Excavations revealed a multi-component occupation. Cultural material included an extensive burned rock midden with remains dating from the Middle Archaic through the Late Prehistoric. Below the midden $(60-75 \mathrm{cmbs})$ was evidence of a PaleoIndian component. In 1977, a University of Texas at San Antonio field school resumed the excavations exposing two large areas where Paleoindian material had been found. Late Paleo-Indian artifacts were found $60-75 \mathrm{cmbs}$ on top of a gravel lens. According to the geomorphologists that worked 
at the site, the early occupation materials (Golondrina and Angostura points) are in situ (Hester 1977).

Site 41BX1007 was recorded in 1994 by C. K. Chandler. The site is located immediately west of Salado Creek. The site consists of a Late Prehistoric occupation site that contains a midden, burned rock, Scallorn points and one triangular point. No subsurface testing was conducted but the depth of cultural deposits was estimated to be as much as one meter. No recommendations as to NRHP status were noted (THC 2008).

The proximity of two sites $41 \mathrm{BX} 17$ and $41 \mathrm{BX} 271$ and a more accurate plotting of the earlier site, 41BX17, indicate that both are part of a prehistoric site once located on a small knoll overlooking the east bank of Salado Creek (Thompson 2006). The western margin of the site known as $41 \mathrm{BX} 17$ originally extended at least $50 \mathrm{ft}$. into the highway right-of-way where Harvey Kohnitz first identified it in the early 1960s. The majority of the site appears to extend for an unknown distance southward and beyond the fence line into property recently purchased by the City of San Antonio (Córdova et al. 2005).

Site 41BX17 has undergone several excavations. Archaeological investigations suggest the occupation of the site spans from about 4000 B.C. to A.D. 1200 as evidenced by the styles of projectile points uncovered from early excavations (Córdova et al. 2005; Thompson 2006; Schuetz 1966). The University of Texas at San Antonio conducted archeological significance testing at 41BX17 from January to March 2006 (Thompson 2006). The distribution of the artifacts, the geomorphic investigations, the radiocarbon assays, and temporally diagnostic artifacts indicate the presence of Middle and Late Archaic archaeological materials with good stratigraphic integrity. Radiocarbon dates and preliminary artifact analysis suggests that prehistoric human occupation at the Granberg Site spanned 3000 years from the Middle Archaic to the Late Archaic (Thompson 2006). 



\section{Chapter 3: Field and Laboratory Methods}

The Center for Archaeological Research was contracted by Adams Environmental Inc., to provide the following archaeological services: 1) Conduct a pedestrian survey accompanied by shovel testing to identify and document all prehistoric and historic archaeological sites that may be impacted by the proposed improvements within the specific Areas of Potential Effect (APE); 2) revisit and shovel test any previously recorded sites that are located in the project ROW or located on city-owned parcels that are adjacent to the alignment. This chapter presents the field and laboratory methods used during the archaeological investigations of the Phase II Salado Creek Greenway Project.

\section{Pedestrian Survey and Shovel Testing of the Alignment}

The archaeological investigation of the proposed trail alignment consisted of an intensive pedestrian survey accompanied by shovel testing. Shovel testing was employed to determine the depth of soil deposits as well as the horizontal and vertical distribution of any cultural material in the project area.

Based on the alignment length (approximately 2.5 miles), shovel testing required to fulfill the THC minimum survey standards for linear projects less than 30 meters wide was a minimum of 40 shovel tests (STs), at a density of 16 STs per mile. Shovel test locations were evenly distributed along the ROW on the floodplains and terraces abutting the active channel. Shovel test locations were recorded using a Trimble Geo XT GPS unit and they were also plotted on an aerial map of the project area. Shovel tests were $30 \mathrm{~cm}$ in diameter and excavated to a depth of $60 \mathrm{~cm}$ below surface $(\mathrm{cmbs})$. They were excavated in 10-cm increments, and all soil from each level was screened through $1 / 4$-inch hardware cloth. All encountered artifacts were recovered with appropriate provenience for laboratory processing, analysis, and curation. A shovel test form was completed in pencil for every excavated shovel test. Data collected from each shovel test included the final excavation depth, a tally of all materials recovered from each 10-cm level, and a brief soil description (texture, consistency, Munsell color, inclusions). Any additional observations considered pertinent were included as comments on the standard shovel test excavation form.

\section{Revisiting Previously Recorded Sites}

In addition to the pedestrian survey of the proposed trail alignment, the Phase II survey also included revisiting previously recorded sites that were located on cityowned parcels, adjacent to the proposed trail alignment. The previously recorded sites were relocated by using aerial photographs and GPS units that contained the UTM coordinates of the sites (obtained from the Texas Archeological Sites Atlas). Once a site was relocated, crewmembers made written observations regarding the types of cultural materials noted on surface, the relative density of artifacts and temporal diagnostics. Additional shovel tests (1 to 5) were excavated within previously recorded sites. Site 41BX841 was the only previously recorded site that was located on the proposed trail alignment.

\section{Site Recording and Identification}

For the purposes of this survey, newly encountered archaeological sites were defined as locations containing cultural materials or features that are at least 50 years old within a given area. The definition of a site used for this project was as follows: (1) Five or more surface artifacts within a 15meter radius (ca. $706.9 \mathrm{~m} 2$ ), or (2) a single cultural feature, such as a hearth, observed on surface or exposed in shovel testing, or (3) a positive shovel test containing at least three artifacts within a given $10-\mathrm{cm}$ level, or (4) a positive shovel test containing at least five total artifacts, or (5) two positive shovel tests located within 30 meters of each other.

When an artifact concentration was identified as a site, crew members established a datum consisting of a rebar hammered into the ground at the site's center. Shovel test locations were recorded with a GPS unit. Standardized site forms containing observations about artifact distribution, vegetation, artifact densities and features were completed. In addition, sketch maps showing site boundaries, datum locations, shovel tests, collected items, archaeological features and physical features of the landscape were drawn. Texas site forms were prepared for all newly documented sites to request a trinomial.

Artifacts encountered that did not meet the minimum requirements for a site were treated as isolated finds. These artifacts were recorded with a GPS unit and their locations were plotted on the maps and aerials. Only those isolated finds that were temporally diagnostic were collected.

\section{Laboratory Methods}

All cultural material collected during the survey was prepared in accordance with federal regulation 36 CFR part 
79, and in accordance with current guidelines of the Center for Archaeological Research. Artifacts were processed in the CAR laboratory where they were washed, air-dried, and stored in archival-quality bags. Artifacts were sorted into appropriate analytical categories. Acid-free labels were placed in all artifact bags. Each label displayed provenience information and a corresponding lot number laser printed or written in pencil.

Artifacts were separated by class and stored in acid-free boxes identified with standard labels. The data was entered into a
Microsoft Access database. All artifacts were permanently curated at CAR.

Field notes, forms, and hard copies of photographs were placed in labeled archival folders. All field forms were completed in pencil. Documents and forms were printed on acid-free paper and any soiled forms were placed in archivalquality page protectors. A copy of the final report in Adobe Acrobat ${ }^{\circledR}$ file format and all digital material pertaining to the project, including photographs, were placed onto a $\mathrm{CD}$ and permanently curated with the field notes and documents at the Center for Archaeological Research. 


\section{Chapter 4: Results of Archaeological Investigations}

The Phase II pedestrian survey of the Salado Creek Greenway project was completed in February 2008. This chapter discusses the results of the pedestrian survey of the APE. Archaeological investigations consisted of an intensive pedestrian survey accompanied by shovel testing along the proposed trail alignment located between N. E. Loop 410 and Wetmore Road (Figure 4-1). Investigations also included revisiting previously recorded site 41BX841, located within the city-owned parcels adjacent to the proposed trail alignment ROW. Three new field sites (41BX1764, 41BX1765 and 41BX1766) were identified and recorded as a result of archaeological investigations.

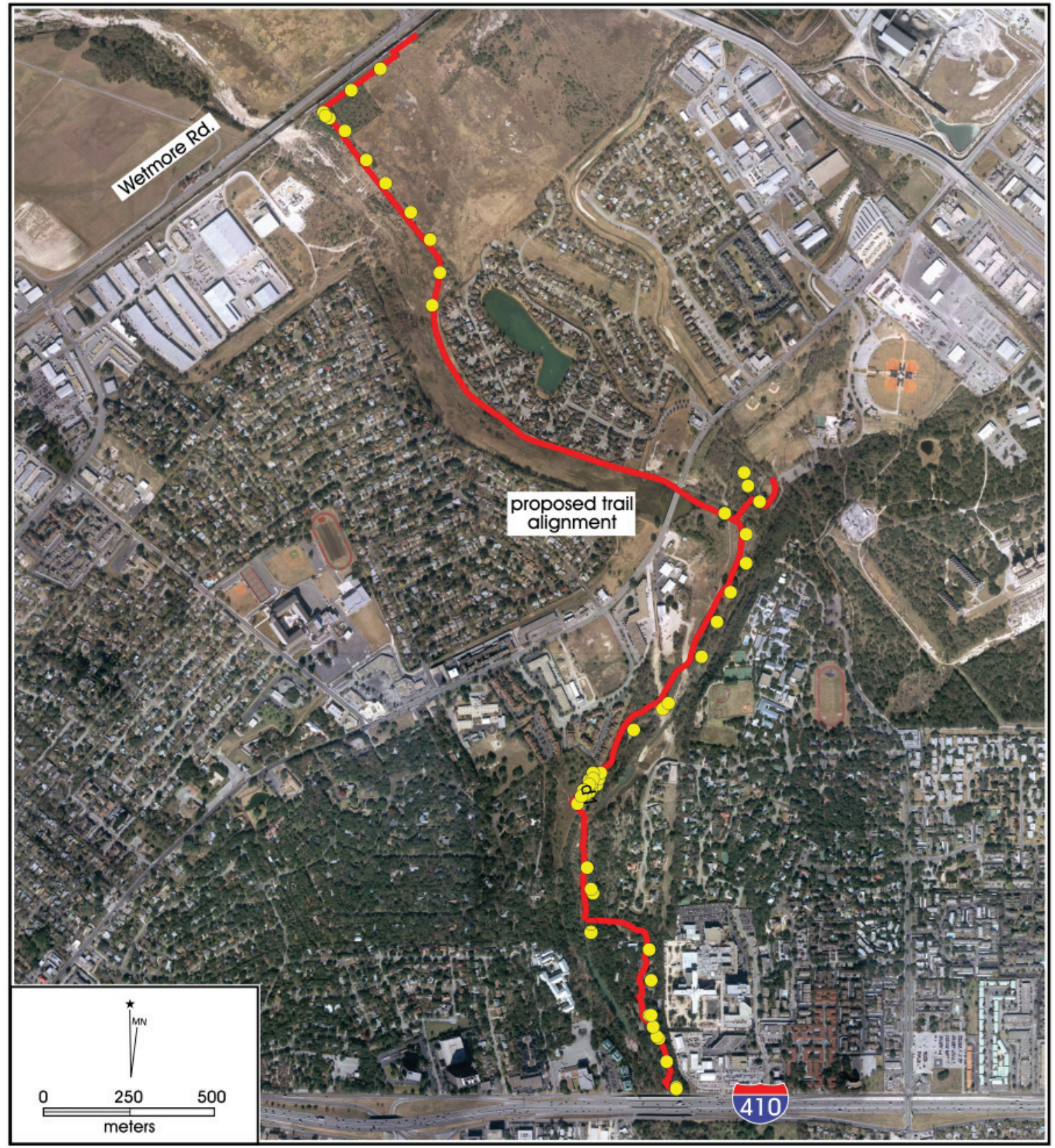

Figure 4-1. Shovel tests along Area of Potential Effect. 


\section{Pedestrian Survey and Shovel Testing of the Alignment}

Forty-eight shovel tests were excavated during the survey of Phase II of the Salado Creek Greenway project. Two isolated finds were recorded (ST 10 and ST 35). Twelve shovel tests were excavated in the extreme southern portion of the project area, north of Loop 410 within the environs of Los Patios. This portion of the proposed trail corridor is east of the Salado Creek in a floodplain. Piles of gravels, likely related to landscape activities were present in the area. Furthermore, natural alluvial gravels and exposed bedrock were also visible on the surface in this area (Figures 4-2 and 4-3). Soils in this area contained alluvial gravels, with the exception of Shovel Test 1, which consisted of loose grey sand, along with modern debris. The construction related to Loop 410 could

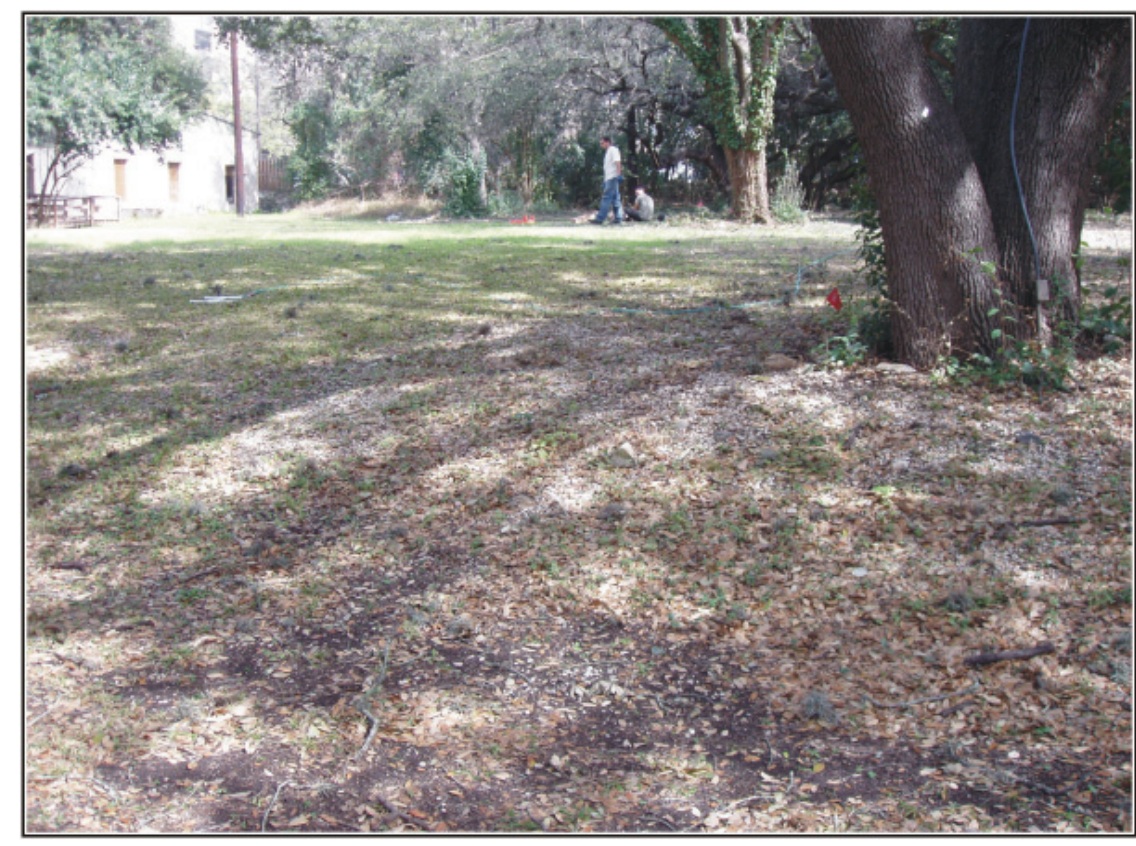

Figure 4-3. Natural gravels visible on the ground surface. account for the evidence of fill in this area as the shovel test was excavated 10-15 m from the Loop 410 ROW. Three of the shovel tests excavated in this area terminated at $60 \mathrm{cmbs}$. The remainder of shovel tests terminated at $20-25 \mathrm{cmbs}$ due to the high density of impenetrable gravels. Shovel Test 35 was positive for cultural material with one piece of lithic debitage. An additional shovel test was excavated to the north but was negative for cultural material. Therefore, the debitage retrieved in ST 35 was classified as an isolated find.

Shovel Tests 3 and 37 were positive for cultural material and recorded as 41BX1765. The details of the site are presented in the site discussion section of this chapter.

Along the APE, between the Los Patios shopping area and the LBJ Park, 24 shovel tests were excavated. The proposed trail corridor in this area is located on the west bank of the Salado Creek and runs along a T2 terrace. A segment of proposed alignment descends off the terrace, in a northerly

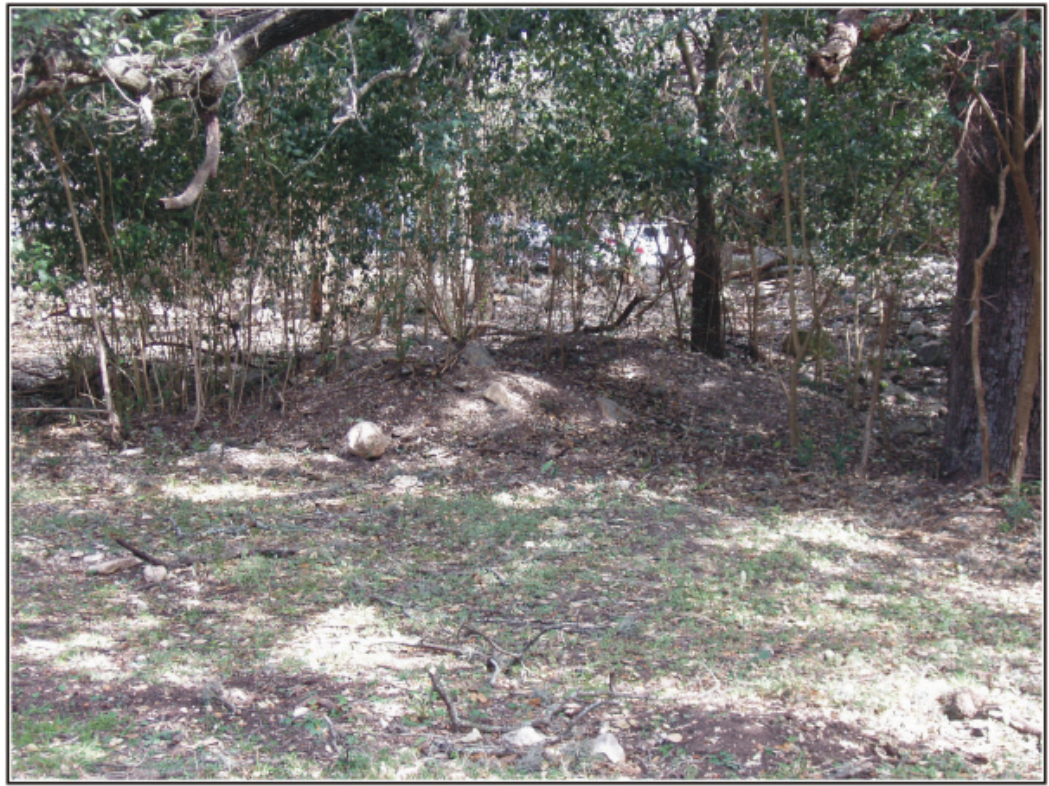

Figure 4-2. Gravels associated with landscaping activities along the Los Patios portion of the project area. direction, onto the floodplain. At the LBJ Park location a portion of the proposed trail corridor crosses the creek channel and ascends another T1 terrace onto the park. Shovel testing on T1 terraces revealed dark brown silty clay, while those placed in the floodplain consisted of sandy clay with a high density of gravel inclusions (30 to $50 \%$ ). Out of the 24 shovel tests excavated along this portion of the APE, seven were positive for cultural material. Positive shovel tests located on the T1 terrace (north of Los Patios) contained lithic debitage, burned rock and one lithic tool. Positive shovel tests excavated in the existing floodplain contained a mixture of prehistoric and modern debris.

The remaining northern portion of the proposed trail alignment continues north from LBJ Park to Wetmore Road. From Nacogdoches Road heading north, a $980 \mathrm{~m}$ portion of the trail is located in the creek channel and is bound to the 
east and west by residential development (Figure 4-4). No shovel testing occurred within the creek channel. Thereafter, the proposed trail runs on the east bank of the creek to Wetmore Road, south of the railroad tracks.

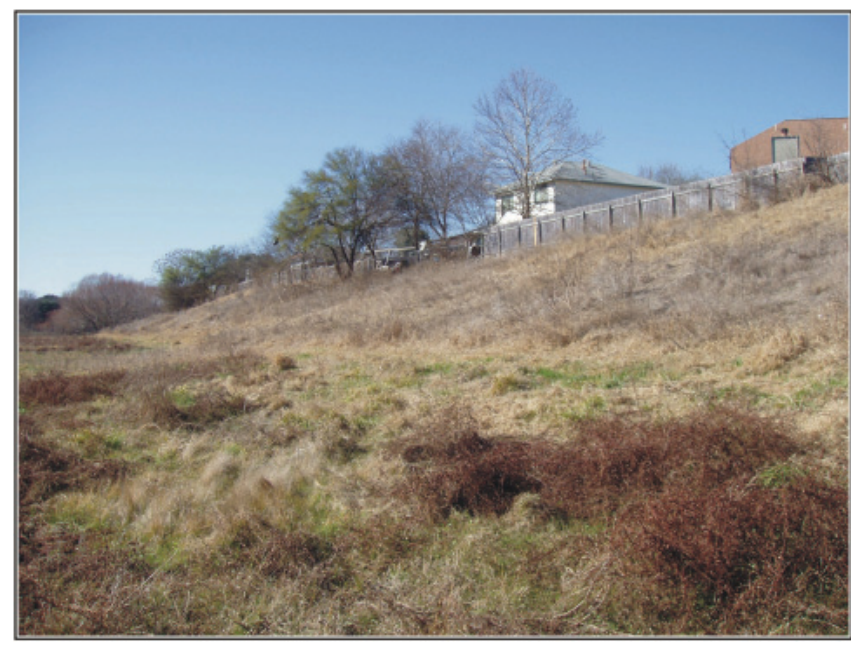

Figure 4-4. Residential properties bounding the Salado Creek channel, north of Nacogdoches Road.

On the northern most reach of the proposed trail twelve shovel tests were excavated. Shovel tests revealed shallow compact soils that contained a high density of gravels. One isolated find was encountered in this portion of the APE in ST 10. The shovel test contained one piece of lithic debitage, metal and glass in Level 1 (0-10 cmbs). Two additional shovel tests, excavated to the north and south of ST 10, were void of cultural material.

\section{Revisit of 41BX841}

While surveying the alignment near the LBJ Park, site 41BX841 was revisited. The site has been impacted by previous park improvements and by natural erosion occurring along the banks of the creek. Three shovel tests were excavated within the site boundaries. Only one of the three shovel tests was positive for cultural material. Cultural material retrieved from the shovel test consisted of lithic debitage (Levels 1-6) and burned rock (Levels 1, 4, and 5). The site will not be impacted by the proposed trail corridor, therefore further work is not recommended on the site. If future park improvements are proposed in the environs of the site then further investigations may be required.

\section{New Sites}

During the investigations archaeological sites 41BX1764, 41BX1765 and 41BX1766 were identified and recorded. The newly identified sites were documented as per the methods section of this report. 41BX1764 and 41BX1765 were identified as prehistoric sites, while 41BX1766 contained prehistoric and historic materials. Sites 41BX1765 and 41BX1766 are believed to be the result of flooding events associated with the Salado Creek and are not recommended for further work.

\section{BX1764}

Site 41BX1764 was located on the western banks of the Salado Creek situated on a T2 terrace (Figure 4-5). Three small drainages cross cut the site, two marking its northern and southern boundaries. The eastern portion of the site has been impacted by an existing trail. The proposed trail corridor will be along the pre-existing trail. Vegetation in the environs of the site includes live oak and greenbrier. Surface visibility was low (10\%) and no artifacts were observed on the ground surface. Thirteen shovel tests were excavated to determine the vertical and horizontal extent of the cultural material. Shovel tests excavated along the central axis of the site revealed dark brown silty clay. Those excavated on the

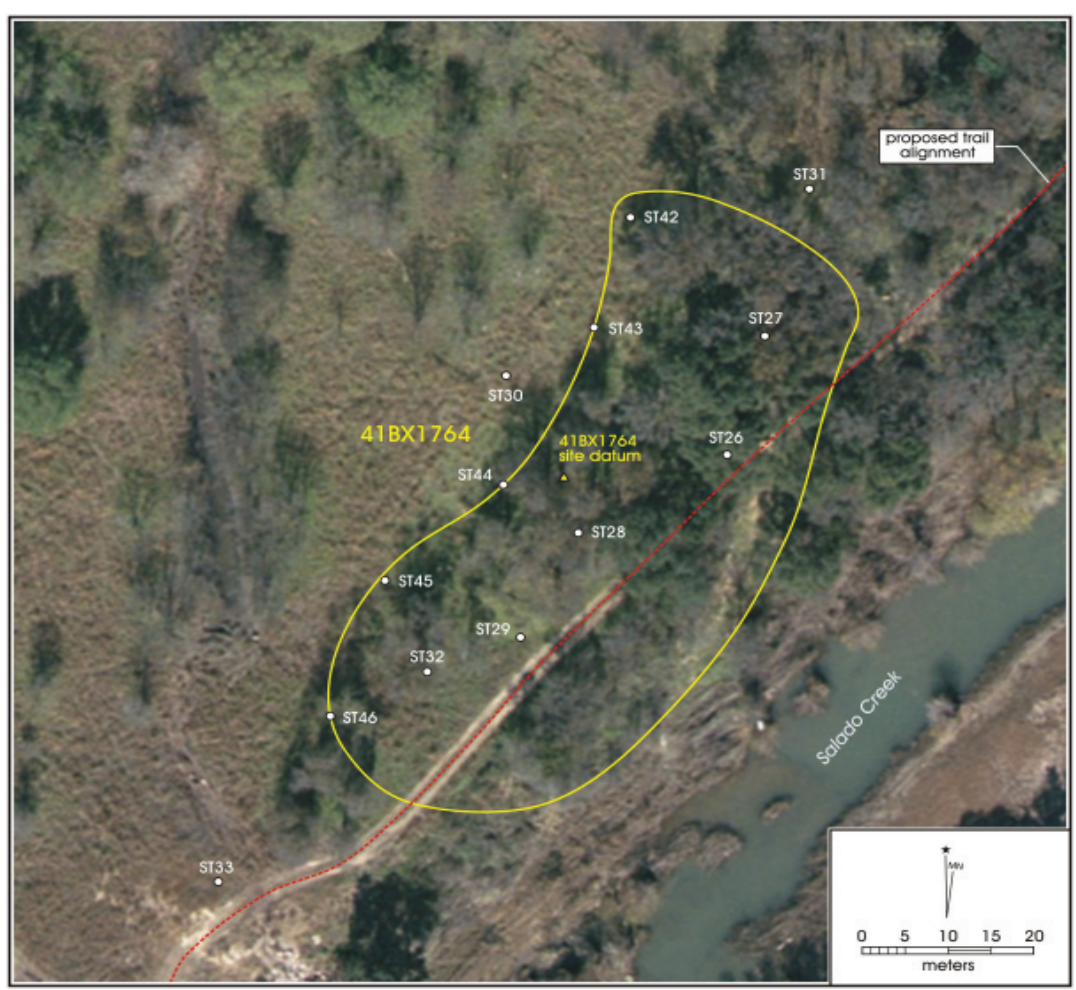

Figure 4-5. A map showing the location of shovel tests and the site boundaries of $41 B \times 1764$. 
western fringes contained heavy gravels $(<50 \%)$ in the first three levels followed by a sterile, dark brown, silty clay. Five of the shovel tests were positive for cultural material (Table 4-1). Debitage was the predominant material type recovered from the site $(n=22)$, followed by burned rock $(n=3)$. A Perdiz projectile point was recovered from Level 2 (10-20 cmbs). The greatest amount of material was present in Level $1(n=12)$, gradually decreasing in the lower levels. There was a second peak of material in Level $6(n=4)$ as depicted in Figure 4-6.

The Perdiz projectile point identified in Level 2 clearly indicates a Late Prehistoric occupation. Furthermore, the vertical distribution of artifacts suggests a second component, represented by the increase in artifacts seen in Level 6 (50-60 cmbs). The CAR recommends that $41 \mathrm{BX} 1764$ is potentially

Table 4-1. Cultural Material Recovered from Shovel Testing at 41BX1764

\begin{tabular}{|c|c|c|c|c|c|}
\hline $\begin{array}{c}\text { Shovel } \\
\text { Test }\end{array}$ & Level & $\begin{array}{c}\text { Burned } \\
\text { Rock }\end{array}$ & Debitage & $\begin{array}{c}\text { Projectile } \\
\text { Point }\end{array}$ & Grand Total \\
\hline \multirow[t]{2}{*}{26} & 2 & 0 & 0 & 1 & 1 \\
\hline & 3 & 0 & 1 & 0 & 1 \\
\hline \multirow[t]{3}{*}{27} & 1 & 0 & 1 & 0 & 1 \\
\hline & 2 & 0 & 3 & 0 & 3 \\
\hline & 3 & 0 & 1 & 0 & 1 \\
\hline \multirow[t]{3}{*}{28} & 1 & 2 & 6 & 0 & 8 \\
\hline & 2 & 0 & 1 & 0 & 1 \\
\hline & 6 & 0 & 2 & 0 & 2 \\
\hline \multirow[t]{3}{*}{29} & 1 & 0 & 1 & 0 & 1 \\
\hline & 4 & 0 & 1 & 0 & 1 \\
\hline & 6 & 0 & 2 & 0 & 2 \\
\hline \multirow[t]{3}{*}{32} & 1 & 0 & 2 & 0 & 2 \\
\hline & 3 & 0 & 1 & 0 & 1 \\
\hline & 4 & 1 & 0 & 0 & 1 \\
\hline \multicolumn{2}{|c|}{ Grand Total } & 3 & 22 & 1 & 26 \\
\hline
\end{tabular}

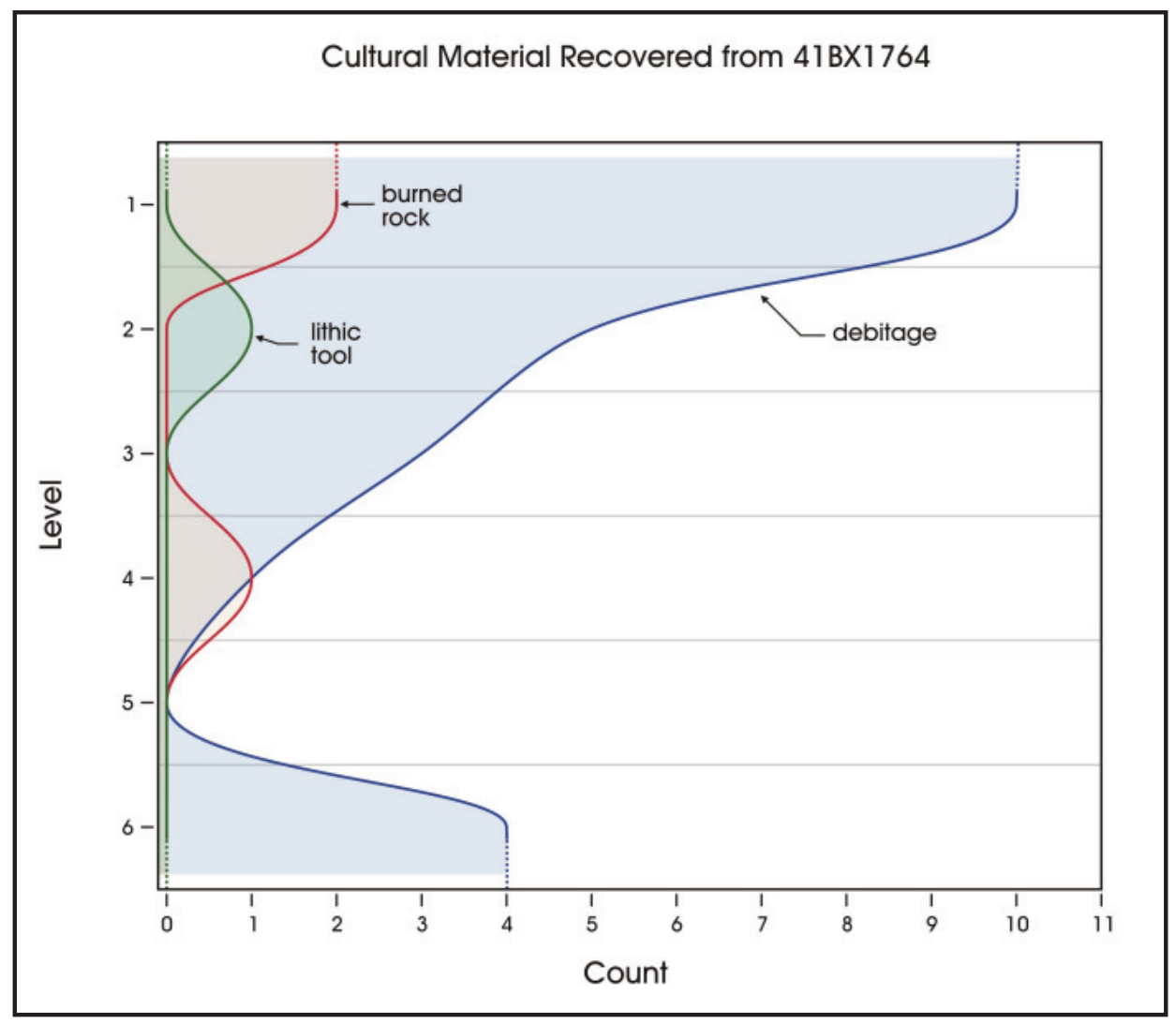

Figure 4-6. Line graph showing the distribution of cultural material, per level, at 41BX1764. 
eligible for listing in the National Register of Historic Places. The site is in jeopardy of secondary impacts associated with the proposed trail improvements (that is along the pre-existing trail). CAR recommends that the proposed trail corridor be relocated or that eligibility testing occur on the site.

\section{BX1765}

41BX1765 was located just north of Loop 410, east of the Salado Creek within the floodplain (Figure 4-7). The area has been modified by several structures, a paved road and parking lots associated with Los Patios. The vegetation in the area consists of live oak and domestic grasses. Shovel testing in the area revealed a high density of alluvial gravels that represents localized flooding events. The site is defined by two positive shovel tests that contained debitage $(n=1)$ and one base of an unidentifiable projectile point. Both lithics show evidence of stream rolling and the projectile point base is heavily patinated. The cultural material recovered at the site appears to be in secondary context and lacks integrity. Further work is not recommended at the site. The CAR recommends that the site is not eligible for NRHP nomination.

\section{BX1766}

Site 41BX1766 is located west of Salado Creek within the floodplain (Figure 4-8). The surface of the site is covered by gravels, associated with high energy flooding events. The site is defined by one shovel test that contained a mixture of modern and prehistoric material. Two additional shovel tests in the site vicinity were negative for cultural material. Level $2(10-20 \mathrm{cmbs})$ of the positive shovel test contained glass $(\mathrm{n}=63)$. Metal $(\mathrm{n}=1)$, debitage $(\mathrm{n}=1)$ and burned rock $(n=1)$ were present in Level 3. Level 4 contained debitage $(\mathrm{n}=5)$ and Level 5 contained debitage $(\mathrm{n}=1)$, burned rock $(n=2)$ and road $\operatorname{tar}(n=1)$. The final level of the shovel test, Level 6, contained glass $(n=1)$, burned rock $(n=2)$, debitage $(\mathrm{n}=5)$, plaster $(\mathrm{n}=1)$ and faunal material $(\mathrm{n}=1)$. A wooden post spans the shovel test from Level 3 to its terminal depth $(60 \mathrm{cmbs})$. It is evident from the mixture of cultural material and the high density of gravels that the deposits are in a secondary context. Further work is not recommended at 41BX1766 and the site is not recommended as eligible for listing on the NRHP.

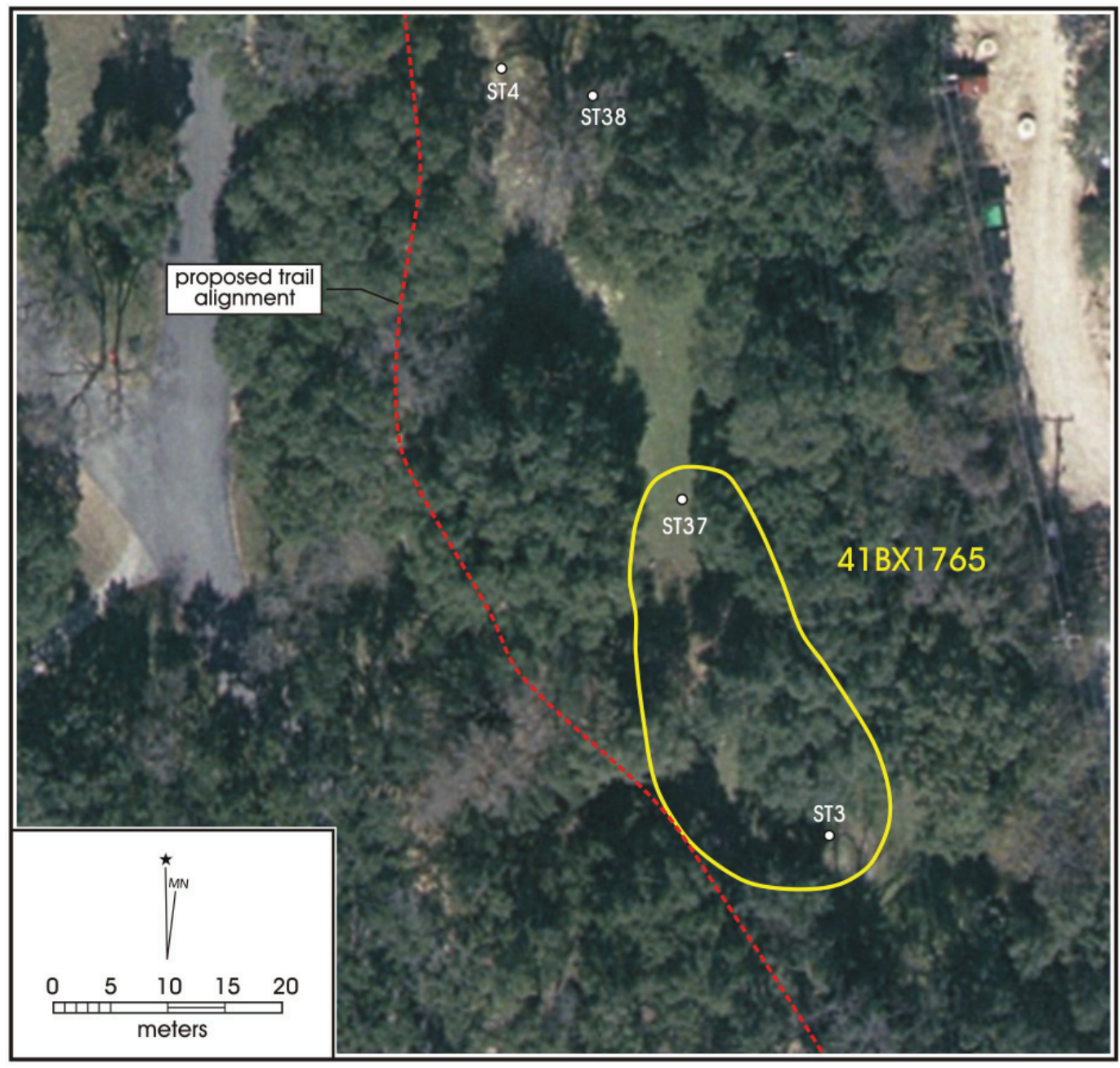

Figure 4-7. A map showing the location of shovel tests and the site boundaries of 41BX1765. 


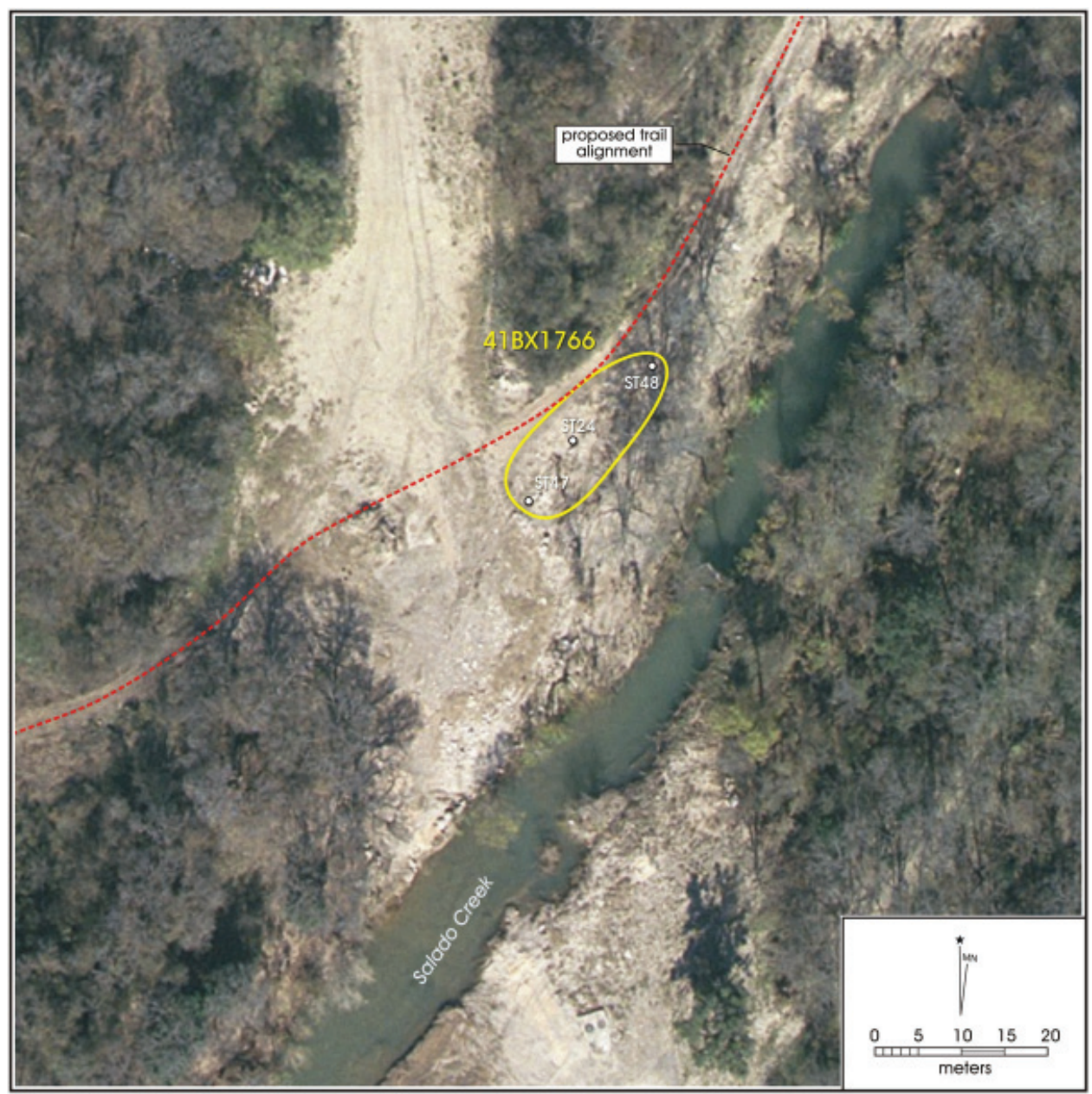

Figure 4-8. A map showing the location of shovel tests and the site boundaries of 41BX1766.

\section{Summary}

The CAR conducted an intensive pedestrian survey and shovel testing of the Phase II portion of the Salado Creek Greenway project. Site 41BX841 was revisited during the investigations. Cultural material was only recovered from one of the three shovel tests excavated. The proposed trail corridor will not impact the site and further work is not recommended.
Results from the investigations included identifying and recording three new sites and documenting two isolated finds. Site 41BX1764 was identified as a prehistoric site with a Late Prehistoric component. The CAR recommends that the site be avoided during the proposed trail improvements. If it cannot be avoided eligibility testing is recommended. 41BX1765 was also identified as a prehistoric site. 41BX1766 contained prehistoric and historic material. Due to the disturbed nature of both sites, further work is not recommended. 


\section{Chapter 5: Conclusions and Recommendations}

In February 2008, The Center for Archaeological Research of The University of Texas at San Antonio conducted a pedestrian survey of the Phase II portion of the Salado Creek Greenway project. The pedestrian survey included shovel testing and the revisit of site 41BX841. The purpose of the archaeological investigations was to identify and document all prehistoric and historic resources that may be impacted by the proposed improvements.

As a result of the pedestrian survey 48 shovel tests were excavated. A good portion of the proposed trail is within the creek channel and along its floodplain. No shovel tests were excavated within the stream channel. Site 41BX841 was revisited by the CAR during the archaeological investigations. One of the three shovel tests excavated on the site was positive for cultural material. Since impacts from the proposed trail corridor will occur south of the site further work is not recommended. However, if future improvements should impact the site further work is recommended.

Three new field sites, 41BX1764, 41BX1765 and 41BX1766 were identified and recorded during the archaeological work. The CAR recommends that both 41BX1765 and 41BX1766 are not eligible for NRHP listing due to their disturbed context along the floodplain of the Salado Creek. The CAR does not recommend further work on either site.

Site 41BX1764 contained a Late Prehistoric component, indicated by the excavation of a Perdiz projectile point. Shovel testing of the site recovered a high frequency of debitage and burned rock. The CAR recommends that 41BX1764 is potentially eligible for the NRPH under criterion D. The continued use of the existing trail will possibly result in direct and s-econdary impacts to 41BX1764. The proposed trail alignment, which is along the pre-existing trail, will potentially impact the site as well. Therefore, the CAR recommends eligibility testing at 41BX1764.

A third segment of the trail corridor, located north of Wetmore, was to be included in the Phase II survey. This portion of the trail corridor has not been finalized. Once the route has been determined further work may be recommended. Results of the survey of that portion of the trail alignment will be presented in a separate letter report. Also, the construction of the trailhead in the vicinity of the Granberg site (41BX17) is currently ongoing. Some utility installations have occurred and remain to be completed. The CAR staff members have monitored these installations and the results of their monitoring will also be discussed in the letter. 



\section{References Cited}

Black, S.L. and D.G. Creel

1997 The Central Texas Burned Rock Midden Reconsidered. In Hot Rock Cooking on the Greater Edwards Plateau: Four Burned Rock Midden Sites in West Central Texas, edited by S. Black, L.W. Ellis, Creel, and Goode, pp.269-305. Studies in Archeology 2. Texas Archeological Research Laboratory, The University of Texas at Austin.

Chapa, J. B.

1997 Historia del Nuevo Reino de Leon. In Texas and Northeastern Mexico, 1630-1690, edited by J. Bautista Chapa and W. C. Foster, p. 91. Translated by N. F. Brierly, University of Texas Press, Austin.

Collins, M.B.

1995 Forty Years of Archeology in Central Texas. Bulletin of the Texas Archaeological Society 66:361-400.

Córdova, K. J., B. K. Moses, and R. P. Mauldin

2005 Records and Collections Assessment of Previous Investigations at Sites 41BX17 and 41BX271 (Granberg I and II) within the ROW of Loop 410 East at Salado Creek, San Antonio, Bexar County, Texas. Report on file at the Center for Archaeological Research, The University of Texas at San Antonio.

Figueroa, A.L and J.L. Thompson

2005 Intensive Pedestrian Survey of the Three Tracts to be Impacted by the Planned Expansion of the San Antonio International Airport, Bexar County, Texas. Archaeological Report, No. 357. Center for Archaeological Research, The University of Texas at San Antonio.

Hester, T.R.

1977 Excavations at St. Mary's Hall (41BX229): A Buried Plainview Campsite in South Central Texas. Paper Presented at the Texas Archeological Society, Arlington, October 28-30.

1995 The Prehistory of South Texas. Bulletin of the Texas Archeological Society 66:427-459.

Munoz, C.M.

2008 An Intensive Pedestrian Archaeological Survey of the Salado Creek Greenway, Wetmore to Eisenhauer Road, San Antonio, Bexar County, Texas, Phase I: N.E. Loop 410 to Eisenhauer Road. Technical Report, No. 8. Center for Archaeological Research, The University of Texas at San Antonio.

Perttula, T.K., M.R. Miller, R.A. Ricklis, D.J. Prikryl, and C. Lintz 1995 Prehistoric and Historic Aboriginal Ceramics in Texas. Bulletin of the Texas Archeological Society 66:175-235.

Potter, D., and S. Black

1995 Archeology Along the Wurzbach Parkway: Module 2 Initial Testing and Evaluation of Five Prehistoric Sites in the Upper Salado Watershed, Bexar County, Texas. Studies in Archeology 18. Texas Archeology Research Laboratory, The University of Texas at Austin.

Potter, D., S. L. Black and K. Jolly

1995 Archeology Along the Wurzbach Parkway: Module 1 Introduction, Conceptual Framework, and Contexts of Archeological Investigations in Bexar County, South-Central Texas. Studies in Archeology Research Laboratory, The University of Texas at Austin. 


\section{Ricklis, R.A.}

1992 The Spread of the Late Prehistoric Bison Hunting Complex: Evidence from the South-Central Coastal Prairie of Texas. Plains Anthropologist 37(140):261-273.

Schuetz, M.K.

1966 The Granberg Site: An Archaic Indian Habitation in Bexar County, Texas. Studies No. 1. Witte Memorial Museum, San Antonio, Texas.

Taylor, F. B., R. B. Hailey and D. L. Richmond

1991 Soil Survey, Bexar County, Texas. Soil Conservation Service, U. S. Department of Agriculture, Washington D. C.

Texas Historical Commission (THC)

2008 Texas Archeological Sites Atlas, http://www.nueces.thc.state.tx.us/>, accessed April 2008.

Thompson, J. L.

2006 National Register of Historic Places/State Archeological Landmark Eligibility Testing of the Granberg Site (41BX17). Manuscript on file. The Center for Archaeological Research, University of Texas at San Antonio.

Turner, S.E., and T.R. Hester

1993 Stone Artifacts of Texas Indians. Second Edition. Texas Monthly and Gulf Publishing Company, Houston.

Vines, R. A.

1960 Trees, Shrubs, and Woody Vines of the Southwest. University of Texas Press, Austin. 